\title{
Specificity of Prohormone Convertase Endoproteolysis of Progastrin in AtT-20 Cells
}

\author{
Chris J. Dickinson, ${ }^{*}$ Mitsutaka Sawada, ${ }^{*}$ Yi-Jun Guo, ${ }^{\star \$}$ Susan Finniss, ${ }^{*}$ and Tadataka Yamada ${ }^{\star \$}$ \\ $*$ Department of Pediatrics, ${ }^{\ddagger}$ Department of Internal Medicine, and ${ }^{\S}$ Department of Physiology, University of Michigan Medical Center, \\ Ann Arbor, Michigan 48109
}

\begin{abstract}
Biologically active peptide hormones are synthesized from larger precursor proteins by a variety of posttranslational processing reactions. Endoproteolytic cleavage at the Lys ${ }^{74}$ Lys $^{75}$ dibasic processing site of progastrin is the major determinant for the relative distribution of gastrin heptadecapeptide and tetratriacontapeptide in tissues. Thus, we explored the ability of two prohormone convertases, PC1/PC3 and PC2, to cleave this important site within progastrin. We expressed wild-type human gastrin cDNA and mutant cDNAs in which the $\operatorname{Lys}^{74} \mathrm{Lys}^{75}$ site was changed to $\mathrm{Lys}^{74} \mathrm{Arg}^{75}, \mathrm{Arg}^{74} \mathrm{Arg}^{75}$, and $\mathrm{Arg}^{74} \mathrm{Lys}^{75}$ residues in AtT-20 cells. Because AtT-20 cells express PC1/PC3 but not PC2, we also coexpressed a cDNA encoding PC2 in both wildtype and mutant gastrin-producing AtT-20 cells. Wild-type Lys $^{74} \mathrm{Lys}^{75}$ and mutant $\mathrm{Arg}^{74} \mathrm{Arg}^{75}$ progastrin processing sites were efficiently cleaved in AtT-20 cells only after coexpression of PC2. Mutant $\mathrm{Lys}^{74} \mathrm{Arg}^{75}$ progastrin was readily processed in cells in the presence or absence of PC2 coexpression, but, in contrast, mutant $\mathrm{Arg}^{74} \mathrm{Lys}^{75}$ progastrin was inefficiently cleaved regardless of $\mathrm{PC} 2$ coexpression. Northern analysis revealed the presence of PC2 but not PC1/ $P C 3$ in canine antral gastrin-producing $G$ cells. These data suggest that PC2 but not $\mathrm{PC1} / \mathrm{PC} 3$ is responsible for the cleavage of the $\mathrm{Lys}^{74} \mathrm{Lys}^{75}$ site in wild-type progastrin. ( $J$. Clin. Invest. 1995. 96:1425-1431.) Key words: posttranslational processing $・$ PC1/PC3, PC2, G34, G17
\end{abstract}

\section{Introduction}

Peptide hormones such as progastrin are synthesized from precursor prohormones by a series of posttranslational processing reactions. Endoproteolytic cleavage of these precursor molecules is performed by compartmentalized intracellular proteases that generate smaller biologically active peptides $(1,2)$. Prohor-

Address correspondence to Chris J. Dickinson, M.D., Department of Pediatric Gastroenterology, University of Michigan Medical Center, 1150 W. Medical Center Drive, A520 MSRB I, Ann Arbor, MI 481090658. Phone: 313-763-2005; FAX: 313-763-2535.

Received for publication 18 November 1995 and accepted in revised form 15 May 1995.

1. Abbreviations used in this paper: FPIC, fast protein liquid chromatography; G17, gastrin heptadecapeptide; G34, gastrin tetratriacontapeptide; PC, prohormone convertase; POMC, proopiomelanocortin.

J. Clin. Invest.

(C) The American Society for Clinical Investigation, Inc.

$0021-9738 / 95 / 09 / 1425 / 07 \quad \$ 2.00$

Volume 96, September 1995, 1425-1431 mone convertases (PCs) ${ }^{1}$ related to the yeast-processing enzyme, kex2, cleave prohormones at dibasic amino acid residues. Two mammalian PCs, PC2 and PC1/PC3, have been characterized and represent the LysArg type-2 (PC2) and ArgArg type1 ( $\mathrm{PC} 1 / \mathrm{PC} 3) \mathrm{Ca}^{2+}$-dependent proinsulin cleavage enzymes (3-9). The selectivity of these enzymes for various prohormone substrates has been studied because endoproteolysis is usually required for peptide bioactivation but has not been clearly defined. In the case of gastrin, the synthesis of gastrin tetratriacontapeptide (G34) involves initial endoproteolytic cleavage at the $\mathrm{Arg}^{57} \mathrm{Arg}^{58}$ and $\mathrm{Arg}^{94} \mathrm{Arg}^{95}$ dibasic processing sites within progastrin (Fig. 1; reference 10). The carboxyterminal $\mathrm{Arg}^{94} \mathrm{Arg}^{95}$ residues are then removed by carboxypeptidase $\mathrm{H}$ to reveal a glycine-extended precursor, G-Gly, that serves as a substrate for the amidation reaction. Complete posttranslational processing with carboxy-amidation of gastrin heptadecapeptide (G17) and G34 is required for binding to gastrin/ CCKB receptors and subsequent biological activity. Indeed, gastrins with either Gly or GlyArgArg carboxy-terminal extensions are at least four orders of magnitude less potent than amidated gastrin in stimulating gastric acid secretion $(11,12)$. Recently, however, we demonstrated that physiologic concentrations of G17-Gly act as a growth factor through action at a receptor distinct from the standard gastrin/CCKB receptor (13).

The Lys ${ }^{74}$ Lys ${ }^{75}$ site of progastrin serves as an attractive model to study processing reactions, because cleavage at this site is responsible for the tissue-specific nature of progastrin processing. For example, G34 predominates in tissue extracts of duodenum and pituitary, whereas $\mathrm{G} 17$ is the major form found in the antrum (14-16). Moreover, although amidated G34 and G17 are equally potent and efficacious at stimulating gastrin acid secretion (17), cleavage of the $\mathrm{Lys}^{74}{ }^{74} \mathrm{~s}^{75}$ processing site is important because $\mathrm{G} 34$ has a longer plasma halflife than does G17 (18). To underscore the biological importance of processing at this site, we noted that G34-Gly does not inhibit binding of radiolabelled [ $\left.{ }^{125} \mathrm{I}\right] \mathrm{G}_{(2-17)}$-Gly to the G-Gly receptor (unpublished observation) in concentrations as high as $10^{-6} \mathrm{M}$. Therefore, an understanding of the mechanisms of processing at Lys ${ }^{74} \mathrm{Lys}{ }^{75}$ is relevant to the biology of both amidated and glycine-extended gastrins.

In vitro studies involving the expression $\mathrm{PC} 1 / \mathrm{PC} 3$ in fibroblasts, followed by an examination of its substrate specificity with small tripeptide substrates, have provided results that conflict with those obtained in cellular expression studies (7-9, 19). Furthermore, small peptide substrates do not permit an examination of the role of amino acids surrounding the cleavage site because of the restricted length of the peptides. In addition, investigators have been unable to express a functional PC2 protein in eukaryotic systems for use in in vitro studies. Thus, in an effort to provide a full characterization of the substrate specificity of the biologically relevant PCs, we examined the processing of full-length progastrins in a normal cellular microenvironment using a heterologous expression system. 


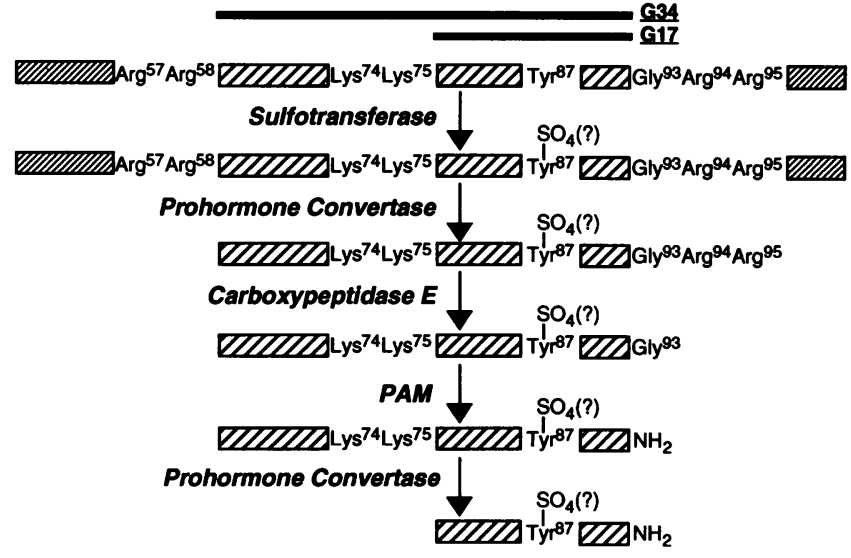

Figure 1. Progastrin processing. The progastrin molecule is shown with the dibasic cleavage sites $\mathrm{Arg}^{58} \mathrm{Arg}^{59}$, $\mathrm{Lys}^{74} \mathrm{Lys}^{75}$, and $\mathrm{Arg}^{94} \mathrm{Arg}^{95}$. After exiting the endoplasmic reticulum, the $\mathrm{Tyr}^{87}$ residue is variably sulfated in the Golgi apparatus. The amino- and carboxy-terminal flanking regions (heavy striped boxes) are then removed by a prohormone convert. Carboxy-terminal processing continues via the removal of the remaining basic amino acid residues by carboxypeptidase $\mathrm{H}$, which results in the formation of a glycine-extended intermediate (G34-Gly). Conversion of the $\mathrm{Gly}^{93}$-extended peptide to a peptide amide via the action of peptidylglycine $\alpha$-amidating monooxygenase (PAM) and cleavage of $\mathrm{Lys}^{74} \mathrm{Lys}^{75}$ via another prohormone convertase completes the conversion of progastrin to amidated G17.

\section{Methods}

Gastrin DNA constructs. Wild-type human gastrin cDNA was a kind gift of Dr. E. Boel (Copenhagen, Denmark) (20). Gastrin cDNAs with site-specific mutations were constructed from this cDNA as previously described $(21,22)$. Trimmed human gastrin cDNA lacking its poly A signal was directionally ligated into $\mathrm{M} 13 \mathrm{mp} 18$ by standard techniques. M13-gastrin viral phage were used to infect CJ 236 (Biorad, Richmond, CA), an Escherichia coli dut $^{-}$ung $^{-}$strain that permits incorporation of uracil into newly synthesized DNA. Single-stranded uracil-containing template DNA was prepared from polyethylene glycol-precipitated phage by phenol-chloroform extraction. Oligonucleotides encoding the desired amino acid changes were synthesized using a DNA synthesizer (Applied Biosystems, Foster City, CA), ethanol precipitated, and phosphorylated with T4 polynucleotide kinase. Aliquots $(3 \mathrm{pmol})$ of the mutant oligonucleotide primer were annealed to $200 \mathrm{ng}$ of uracil containing M13-gastrin template. After annealing, T4 DNA polymerase and T4 DNA ligase were added in the presence of $0.4 \mathrm{mM}$ dNTP to synthesize second strand DNA lacking uracil bases. This duplex DNA was transformed into competent $E$. coli JM101, and phage DNA from individual plaques was prepared for subcloning into the expression vector pLJ. The nucleotide sequence of each mutant DNA was determined by Sanger's method (23)

Infection of endocrine cell lines. For the expression of wild-type and mutant gastrins, we utilized the $\mathrm{pLJ}$ retroviral vector and $\psi$-CRE packaging cell system (24). Briefly, wild-type and mutant gastrin DNAs were prepared as described previously and excised from the M13 vector with EcoRI and BamHI. A synthetic oligonucleotide adapter was used to convert the 5' EcoRI site to a Sal I site to facilitate orientation-directed ligation of the DNA into $\mathrm{pLJ}$. A triple ligation reaction was conducted for $6 \mathrm{~h}$ at $15^{\circ} \mathrm{C}$ in a $10-\mu$ l volume containing $0.055 \mathrm{pmol}$ of $\mathrm{pLJ}$ viral DNA, 0.165 pmol of gastrin DNA, 0.48 pmol of the EcoRI-Sal I adapter, and $10 \mathrm{U}$ of T4 DNA ligase. Correct orientation of the gastrin pLJ constructions was confirmed by restriction mapping. The gastrinpLJ DNA was then transfected into the packaging cell line $\psi$-CRE by standard calcium phosphate coprecipitation, and transfected cells were selected by maintaining the culture in medium containing the neomycin analog G418 ( $1 \mathrm{mg} / \mathrm{ml})$. Medium from the selected cell lines containing gastrin-pLJ DNA was collected and stored at $-70^{\circ} \mathrm{C}$ for later use as viral stock for infection of endocrine cell lines.

AtT-20 endocrine cells were selected for our studies on the basis of some of their known properties. AtT-20 cells are derived from a rat pituitary tumor and express proopiomelanocortin (POMC) gene products. Previous transfection studies have shown that AtT-20 cells process progastrin (25), proneuropeptide $\mathrm{Y}(26)$, and prosomatostatin (27) and thus appear to contain enzymatic activities necessary for dibasic cleavages and carboxy-terminal amidation. More detailed analysis has revealed that they express PC 3 but little, if any, PC2 (5). AtT-20 cells were grown in DME with $10 \%$ horse serum and 5\% FCS. For infection, gastrin-pLJ viral stock was prepared as noted previously, filtered with a $0.22-\mu \mathrm{m}$ filter, and added to $30-50 \%$ confluent target endocrine cells in the presence of $8 \mu \mathrm{g} / \mathrm{ml}$ Polybrene (Aldrich Chemical Co., Milwaukee, WI) for $4 \mathrm{~h}$. The infected cells were grown in complete media at $37^{\circ} \mathrm{C}$ for $48 \mathrm{~h}$, selected in $\mathrm{G} 418(1 \mathrm{mg} / \mathrm{ml})$ containing media for $2 \mathrm{wk}$, and then grown in larger numbers in complete media without neomycin. Cell extracts and media were collected and analyzed for gastrin expression and processing intermediates. Population of cells ( $>200$ clones/ mutant) rather than individual clones were chosen for study to minimize the differences in the posttranslational processing of progastrins that might be observed in single clones with varying levels of gastrin cDNA expression.

To confirm that the infected endocrine cell lines contained the exact mutant that we had transfected into the packaging cells, we determined the nucleotide sequence of gastrin DNA integrated into the target cell genome. DNA was prepared from confluent AtT-20 cells expressing specific gastrin mutants by standard techniques (28). Using oligonucleotides complementary to each end of the inserted human gastrin cDNA, we amplified the entire coding region of the integrated mutant gastrin by PCR (29). The appropriate 400 -bp band was obtained on gel electrophoresis. The oligonucleotide primers contained internal EcoRI and BamHI restriction sites, which were used to cut the PCR product and subclone it into M13 for sequencing (21).

Expression of PC2 in gastrin-producing AtT-20 cells. We utilized a second retroviral vector pBamHis (kind gift of R. Mulligan, MIT, Boston, MA) (30) to coexpress the cDNA encoding PC2 with wildtype and mutant gastrin DNAs in AtT-20 cells. This vector contains all of the elements of the $\mathrm{pLJ}$ vector used for gastrin expression except that the neomycin resistance gene is replaced by a histidinol resistance sequence. This gene provides for the conversion of the cellular toxin histidinol to histidine and thus allows for another method of selecting transformed cells. PC2 cDNA (kind gift of S. Smeekens, University of Chicago, Chicago, IL) (3) was cut from the plasmid pBluescript (-) and digested with BamHI and SalI, purified on a $1 \%$ low melting point agarose gel, and ligated in the sense orientation into pBamHis with $\mathrm{T}_{4}$ DNA ligase for $6 \mathrm{~h} 15^{\circ} \mathrm{C}$. As in the manner of the pLJ-gastrin constructs described previously, the pBamHis-PC2 construct was transfected into $\psi$-CRE cells by calcium phosphate coprecipitation, and transfected cells were selected by incubating the cultures in media containing $2 \mathrm{mM}$ histidinol. An aliquot (1-2 ml) of the viral-containing medium from $\psi$-CRE cells was added to AtT-20 cells that had already been selected for gastrin expression, and histidinol-resistant cells were grown in larger numbers for further study.

RNA analysis. We examined the various transfected cell lines and tissues for expression of PC1/PC 3 and PC2 via Northern hybridization. Total RNA was prepared from each cell line by Chomczynski's acid/ phenol method (31) and from partially purified canine antral endocrine cells as previously described (32) using TRIzol reagent (Gibco Laboratories, Grand Island, NY). Total RNA (10 $\mu \mathrm{g})$ was electrophoresed on $1 \%$ formaldehyde-agarose gels and transferred to Hybond-N filters (Amersham Corp., Arlington Heights, IL) using a Posiblot apparatus (Stratagene, La Jolla, CA). RNA was UV crosslinked to filters and prehybridized in $5 \times$ SSC, $5 \times$ Denhardt's, $0.5 \%$ SDS, and $100 \mu \mathrm{g} / \mathrm{ml}$ salmon sperm DNA for $2 \mathrm{~h}$ at $65^{\circ} \mathrm{C}$. Radiolabeled random-primed cDNA probes were prepared from $\mathrm{PC} 2$ and $\mathrm{PC} 3$ cDNAs (kind gifts of $\mathrm{S}$. Smeekens, University of Chicago, Chicago, IL) with specific activities 
Table I. Amidated Gastrin Production by Transformed Cell Lines

\begin{tabular}{|c|c|c|c|c|}
\hline & \multicolumn{2}{|c|}{ Without PC2 } & \multicolumn{2}{|c|}{ With PC2 } \\
\hline & $\begin{array}{c}\text { Cell extract } \\
\text { (fmol/10 } \\
\text { cells) }\end{array}$ & $\begin{array}{c}\text { Media } \\
(\mathrm{fmol} / \mathrm{ml})\end{array}$ & $\begin{array}{l}\text { Cell extract } \\
\text { (fmol/10 } 10^{6} \\
\text { cells) }\end{array}$ & $\begin{array}{c}\text { Media } \\
\text { (fmol/ml) }\end{array}$ \\
\hline Wild-type Lys ${ }^{74}$ Lys $^{75}$ & $168 \pm 12$ & $21 \pm 5$ & $135 \pm 17$ & $37 \pm 5$ \\
\hline Mutant $\operatorname{Arg}^{74} \operatorname{Arg}^{75}$ & $154 \pm 17$ & $18 \pm 4$ & $162 \pm 9$ & $24 \pm 6$ \\
\hline Mutant Lys $^{74} \mathrm{Arg}^{75}$ & $97 \pm 7$ & $10 \pm 1$ & $66 \pm 9$ & $8 \pm 1$ \\
\hline Mutant $\mathrm{Arg}^{74} \mathrm{Lys}^{75}$ & $116 \pm 10$ & $13 \pm 2$ & $82 \pm 9$ & $12 \pm 3$ \\
\hline
\end{tabular}

Amidated gastrin was assayed with antisera 5135. The data were obtained from $n \geq 6$ samples. Values are mean \pm SEM.

of 1-3 $\times 10^{9} \mathrm{cpm} / \mu \mathrm{g}$. Probes were added to the prehybridization mix and hybridized for $16 \mathrm{~h}$ at $65^{\circ} \mathrm{C}$. Filters were washed repeatedly, with the most stringent conditions being $0.1 \times \mathrm{SSC}, 1 \% \mathrm{SDS}$ at $65^{\circ} \mathrm{C}$ for 1 h. After air drying, the filters were exposed to radiographic film at $-70^{\circ} \mathrm{C}$.

Analysis of gastrin products. Cells were trypsinized, dispersed by pipetting, and counted in a counter (Coulter Immunology, Hialeah, FL). Gastrin-expressing cells were then extracted in boiling water, centrifuged, and stored at $-20^{\circ} \mathrm{C}$ prior to RIA. Extracts were assayed for amidated gastrin using previously described methods $(25,33)$ with antibody 5135 (kind gift of G. Rosenquist, UCLA, Los Angeles, CA), which recognizes both sulfated and unsulfated forms of carboxy-terminal-amidated gastrin G17 and G34. The molecular forms of gastrin produced in each cell line were determined by gel filtration and fast protein liquid chromatography (FPLC). Extracts were applied to Sephadex G-50 superfine columns $(1 \times 120 \mathrm{~cm})$ in $0.025 \mathrm{M}$ sodium barbital buffer, pH 8.4, for size fractionation. Mono-Q anion-exchange FPLC columns (Pharmacia LKB Biotechnology, Piscataway, NJ) were used to characterize further the gastrin molecular forms. The columns were equilibrated with $50 \mathrm{mM}$ Tris, $\mathrm{pH} 8.2,10 \%$ acetonitrile; samples were eluted with a gradient of the same buffer containing $1 \mathrm{M} \mathrm{NaCl}$. Calibration of both columns was performed as previously described $(21,33)$. Recovery of synthetic peptides from both gel filtration and ion-exchange columns was greater than $85 \%$.

To confirm that the expressed gastrin products were sorted to the regulated pathway of secretion, cells were grown to $75 \%$ confluence, washed twice in serum-free media, preincubated with serum-free media for $24 \mathrm{~h}$, and then stimulated with $1.0 \mathrm{mM}$ dibutyrl cAMP for an additional $24 \mathrm{~h}$. Media were then analyzed for the secretion of gastrin by RIA.

\section{Results}

In total, we obtained eight gastrin-producing cell lines, including those expressing wild-type ( $\mathrm{Lys}^{74} \mathrm{Lys}^{75}$ ) and mutant $\mathrm{Arg}^{74}$ $\mathrm{Arg}^{75}$, $\mathrm{Lys}^{74} \mathrm{Arg}^{75}$, and $\mathrm{Arg}^{74} \mathrm{Lys}^{75}$ progastrins with or without coexpression of PC2. As shown in Table I, all eight gastrinproducing cell lines produced substantial quantities of amidated gastrin in both media and cell extracts. We established by DNA sequencing that the specific mutant gastrins had not undergone any changes during the retroviral integration process or following coinfection with the pBamHis/PC2 DNA. The correct complete nucleotide sequence was confirmed for each of the amplified DNAs in all eight cell lines. The amount of gastrin present in cells expressing PC2 was similar to that of cells that did not express PC2 (Table I). The observation that secretion of immunoreactive gastrin into the media was stimulated by dibu-

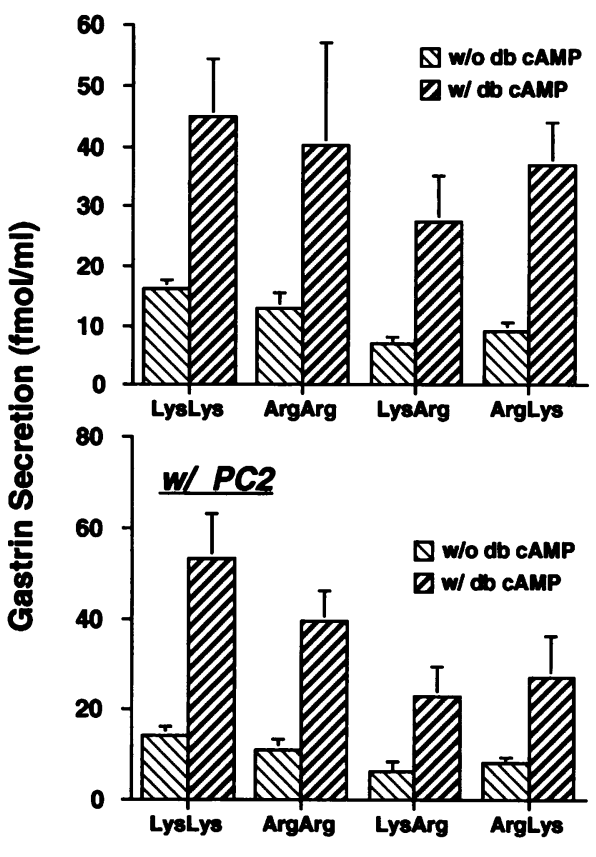

Figure 2. Stimulation of gastrin secretion from transfected AtT-20 cells. Cells were preincubated in serum-free media for $24 \mathrm{~h}$ and then incubated in media with or without added dibutyrl cAMP $(1.0 \mathrm{mM})$ for an additional $24 \mathrm{~h}$. Media were then evacuated from cell cultures and analyzed for gastrin by radioimmunoassay. The top panel represents data from cells expressing wild-type $\left(\mathrm{Lys}^{74} \mathrm{Lys}^{75}\right)$ and mutant $\left(\mathrm{Arg}^{74} \mathrm{Arg}^{75}\right.$,

$\mathrm{Lys}^{74} \mathrm{Arg}^{75}, \mathrm{Arg}^{74} \mathrm{Lys}^{75}$ ) progastrins. The lower panel represents data from cells expressing both gastrin and PC2 cDNAs. The data represent mean $\pm \mathrm{SEM} ; n=6$

tyrl cAMP (Fig. 2) in all eight cell lines indicated that the gastrin products were sorted to the regulated secretory pathway.

Northern blots probed with PC3 cDNA revealed bands of hybridization with RNA from all four gastrin-producing AtT20 cell lines (Fig. 3 ). The size of the hybridizing bands was $2.2 \mathrm{~kb}$. PC2 expression could not be detected in any of the cell

A
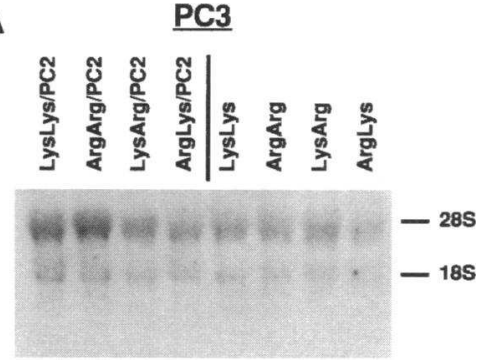

B

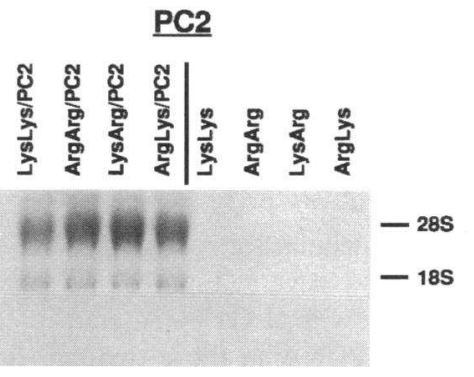

Figure 3. Northern hybridization of RNA from AtT-20 cells expressing wild-type ( Lys $^{74}$ Lys ${ }^{75}$ ) and mutant progastrins with probes for $(A) \mathrm{PC1} /$ $\mathrm{PC} 3$ and $(B) \mathrm{PC} 2$. Aliquots of total RNA from the various cell lines were analyzed as described. Data obtained from AtT-20 cells coexpressing the cDNA encoding PC2 are depicted on the left side of each panel. Neither autoradiogram revealed additional bands of hybridization following more prolonged exposure (data not shown). Ribosomal RNA size markers are indicated as $28 \mathrm{~S}$ and $18 \mathrm{~S}$. 

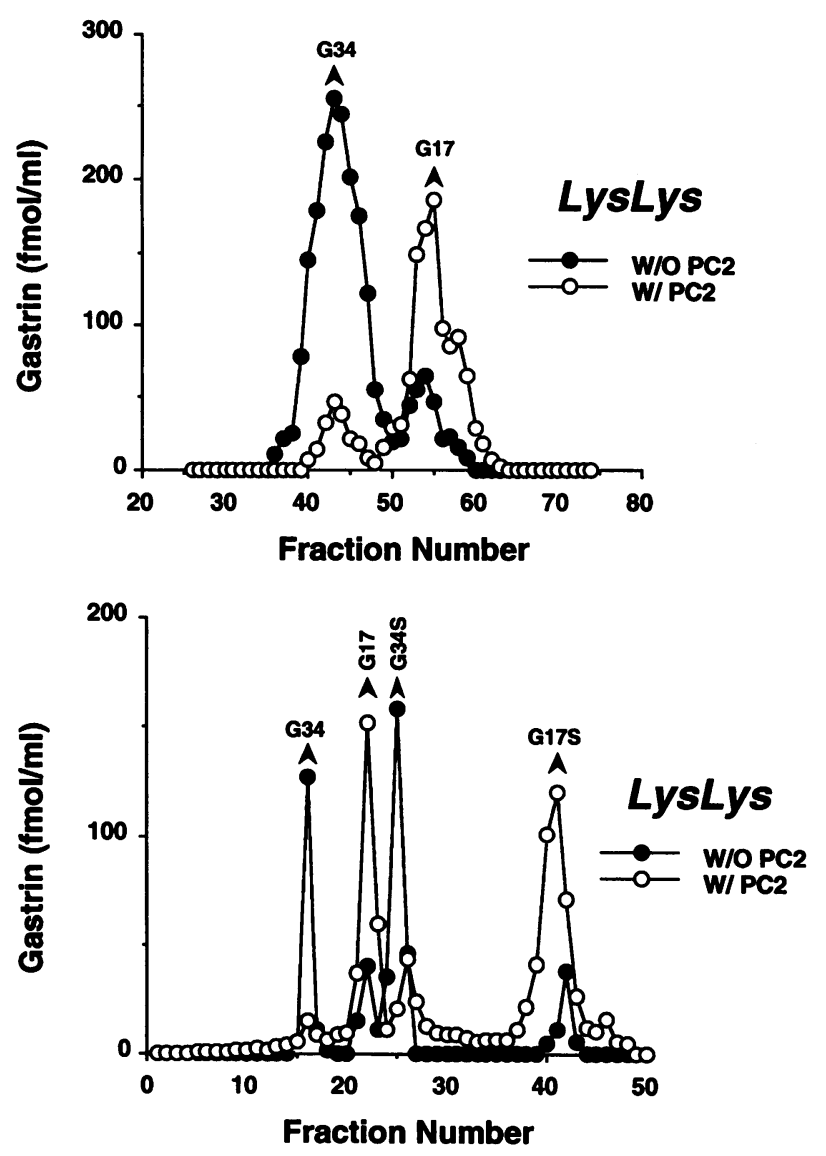

Figure 4. Characterization of gastrin molecular forms in AtT-20 cells expressing wild-type (Lys ${ }^{74}$ Lys $^{75}$ ) progastrin by (top) gel filtration and (bottom) ion-exchange chromatography. For gel filtration chromatography, cell extracts were applied to Sephadex G50 superfine columns (1 $\times 120$ ), and $1.5 \mathrm{ml}$ fractions were collected. Gel filtration columns were calibrated with synthetic G17 and G34 standards. For ion-exchange chromatography, cell extracts were applied to an HR 5/5 Mono-Q FPLC anion-exchange column. Columns were equilibrated with Buffer A (50 $\mathrm{mM}$ Tris, $\mathrm{pH} 8.2,10 \%$ acetonitrile), samples were eluted with a gradient of $1 \mathrm{M} \mathrm{NaCl}$ in Buffer A over $60 \mathrm{~min}$ at $1 \mathrm{ml} / \mathrm{min}$, and fractions ( 1 $\mathrm{ml}$ ) were collected. The ion-exchange columns were calibrated with synthetic standards and extracts of gastric antrum (21) to reveal the elution profiles (arrowheads) for G34, G17, sulfated G34 (G34S), and sulfated G17 (G17S). Fractions from gel filtration and ion-exchange chromatography were assayed for immunoreactive gastrins. Chromatograms of extracts from gastrin-producing AtT-20 cells are shown with closed circles, and those expressing gastrin and PC2 are depicted with open circles. All chromatograms shown are representative of at least three chromatograms from each cell line.

lines that had not been infected with pBamHis-PC2; however, all four cell lines that were coinfected with the pBamHis-PC2 demonstrated PC2 expression (Fig. 3). Coinfection with pBamHis-PC2 did not appear to alter the expression of PC3 in any of the four gastrin-producing cell lines. Expression of a control pBamHis vector without an insert did not alter gastrin or PC3 RNA expression or amidated gastrin peptide production (data not shown).

G34 was the predominant molecular form of gastrin in AtT20 cells expressing wild-type Lys ${ }^{74}$ Lys ${ }^{75}$ (Fig. 4) and mutant $\operatorname{Arg}^{74} \operatorname{Arg}^{75}$ (Fig. 5) progastrins with a G17:G34 ratio of 1:4 (Fig. 6). Coexpression of PC2 cDNA in these two cell lines
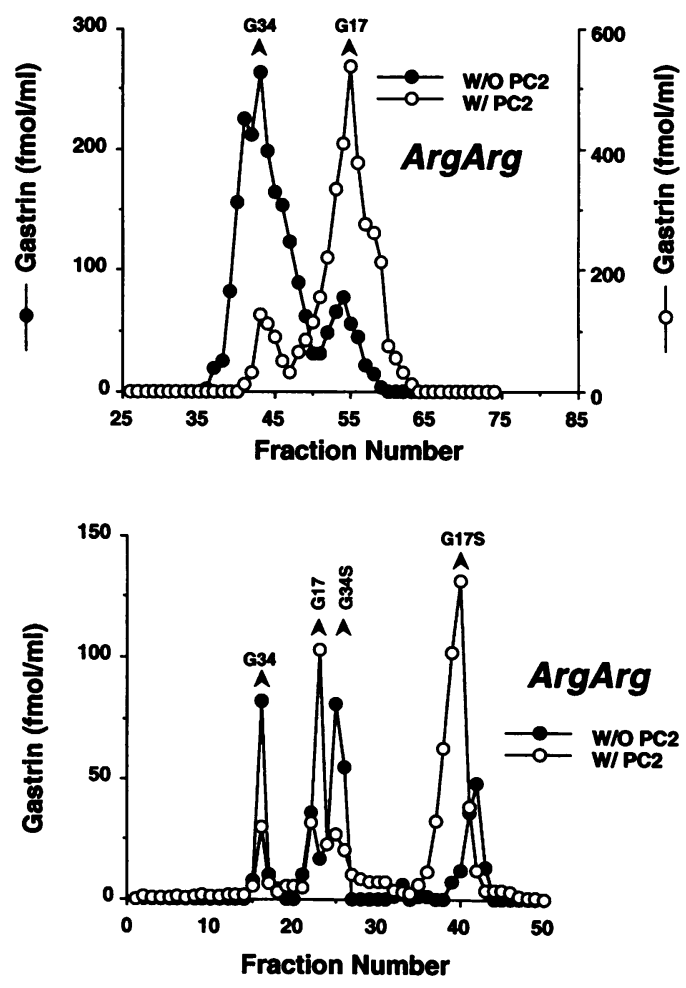

Figure 5. Characterization of gastrin molecular forms in AtT-20 cells expressing mutant $\mathrm{Arg}^{74} \mathrm{Arg}{ }^{75}$ progastrin by (top) gel filtration and (bottom) anion-exchange chromatography as described in figure 4 . The chromatograms shown are representative of at least three from each cell line.

resulted in a reversal of the G17:G34 ratio site from 1:4 to 4:1 (Figs. 4 and 5). Thus, the presence of PC2 converted the predominately G34-producing cell lines into ones that produced predominately G17.

In contrast to the AtT-20 cells expressing wild-type Lys ${ }^{74}$ Lys ${ }^{75}$ and mutant $\operatorname{Arg}^{74} \mathrm{Arg}^{75}$ progastrins, the primary form of gastrin in mutant $\mathrm{Lys}^{74} \mathrm{Arg}^{75}$ progastrin-producing cells was G17, with G17:G34 ratio of 2:1 (Fig. 7). Coexpression of PC2 cDNA in this cell line resulted in slightly greater concentrations of G17 relative to G34 with a G17:G34 ratio of 4:1 (Figs. 6 and 7). In contrast to the other cell lines, AtT-20 cells expressing mutant $\mathrm{Arg}^{74}{ }^{7 y s}{ }^{75}$ progastrin produced primarily G34 both with and without PC2 coexpression (Fig. 8).

FPLC ion-exchange chromatography allowed us to examine the relative amounts of sulfated and nonsulfated amidated gas-

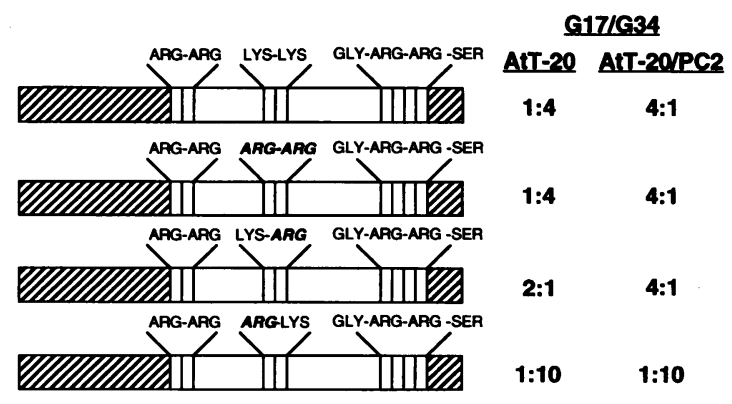

Figure 6. G17:G34 in cell extracts. 

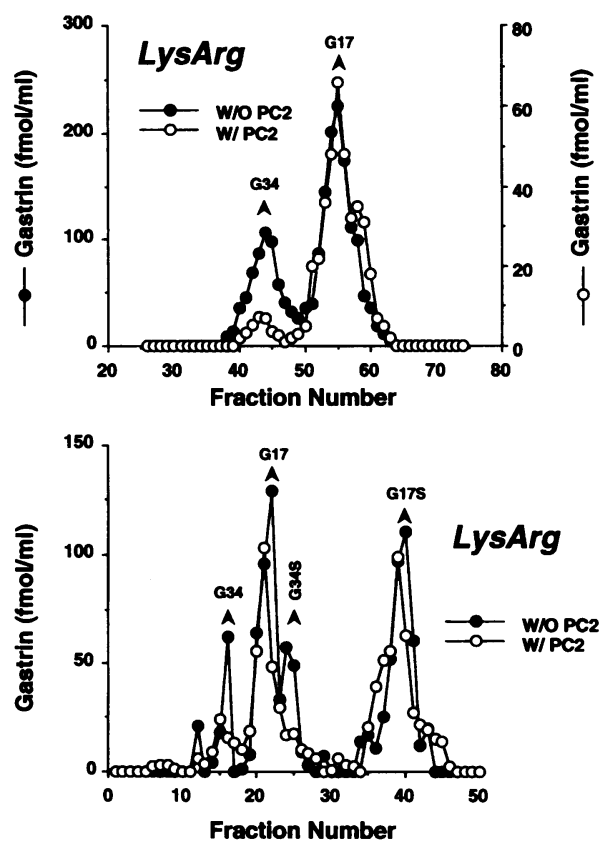

Figure 7. Characterization of gastrin molecular forms in AtT-20 cells expressing $\mathrm{Lys}^{{ }^{74}} \mathrm{Arg}^{75}$ mutant progastrin by (top) gel filtration and (bottom) anion-exchange chromatography as described in Fig. 4. The chromatograms shown are representative of at least three for each cell line.

trins present in cell extracts. The ratio of sulfated-to-nonsulfated gastrins did not vary in any of the eight cell lines (data not shown). Furthermore, there was no difference in the relative amounts of sulfated and nonsulfated forms of G17 and G34.

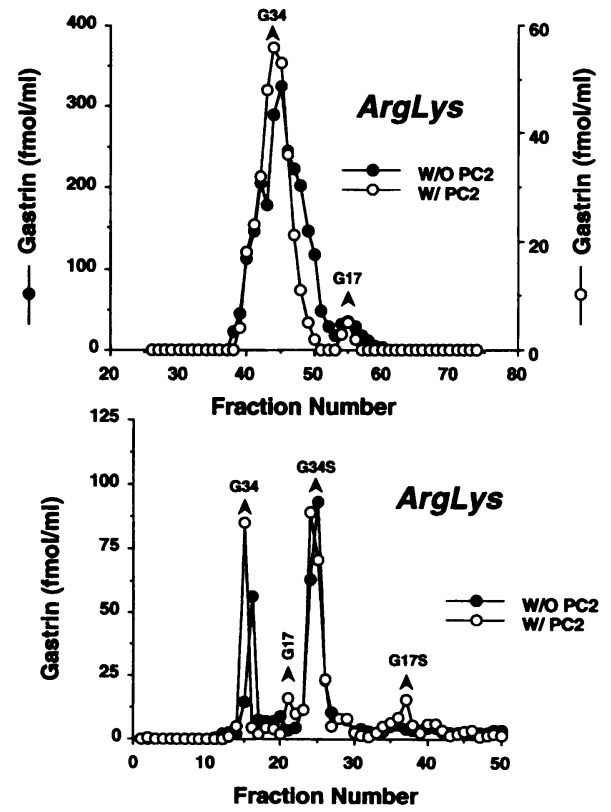

Figure 8. Characterization of gastrin molecular forms in AtT-20 cells expressing mutant $\mathrm{Arg}^{74} \mathrm{Lys}^{75}$ progastrin by (top) gel filtration and (bottom) anion-exchange chromatography as described in Fig. 4 . The chromatograms shown are representative of at least three from each cell line.

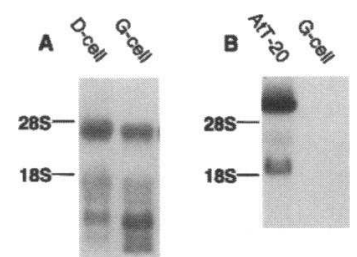

Figure 9. Northern hybridization of RNAs from isolated canine antral gastrin-producing G-cells and somatostatin-producing D-cells. Total RNA was prepared as described, and $10 \mu \mathrm{g}$ aliquots were electrophoresed and probed with the $(A) \mathrm{PC} 2$ or $(B) \mathrm{PC} 1 /$ PC3 cDNA. Neither autoradiogram revealed additional bands of hybridization following a more prolonged exposure (data not shown). RNA from untransformed AtT-20 cells served as a positive control for the PC1/PC3 blot in (B). Ribosomal RNA size markers are indicated as $28 \mathrm{~S}$ and $18 \mathrm{~S}$.

To explore the relevance of our findings to progastrin processing in antral G-cells, we tested for the expression of PC1/ PC3 and PC2 in an enriched population of canine antral Gcells (32). As shown in Fig. 9 we detected PC2 but not PC1/ PC3 expression in these cells. Prolonged exposure of the PC1/ PC3 blot did not result in the appearance of any other bands (data not shown).

\section{Discussion}

Selective endoproteolytic cleavage is a critically important posttranslational processing step for peptide hormones, virtually all of them undergo this reaction. Furthermore, this step in peptide processing accounts for the distinct tissue-specific pattern of distribution of various molecular forms of peptide hormones which often have markedly different biological activities. In the case of progastrin, cleavage at Lys ${ }^{74} \mathrm{Lys}^{75}$ plays a critical role in the bioactivity of amidated and glycine-extended gastrins. Although enzymes such as trypsin are capable of catalyzing dibasic cleavage reactions in vitro (34), the exact nature of the enzymes responsible for dibasic cleavage of prohormones in vivo has been difficult to ascertain (35). Two prohormone convertases ( $\mathrm{PC} 1 / \mathrm{PC} 3$ and $\mathrm{PC} 2$ ) which are expressed only in neuroendocrine tissues have been identified and appear to be responsible for the tissue-specific pattern of prohormone dibasic cleavage reactions $(1,2)$.

In vitro studies involving the expression of the prohormone convertases in fibroblasts, followed by an examination of their substrate specificities using small tripeptide substrates, have provided results frequently at odds with experiments utilizing full-length prohormone substrates in cellular expression systems $(3-9,19,35)$. Accordingly, we conducted our studies in a neuroendocrine cell line, AtT-20, with a well-characterized processing apparatus. We have previously demonstrated the utility of this cell line for examining the posttranslational processing of progastrin (25). Because AtT-20 cells express PC1/PC3 but not PC2 (5), this cell line is a particularly well-suited model for examining the processing of wild-type and mutant progastrins by PC1/PC 3. By subsequently transforming these cells to express PC2, we can also characterize the effect of PC2 on progastrin processing.

Naturally occurring LysLys processing sites are uncommon, and thus we were not surprised that in cells expressing wildtype Lys ${ }^{74} \mathrm{Lys}^{75}$ progastrin, the predominant molecular form of processed gastrin was G34, suggesting poor cleavage of this site by $\mathrm{PC} 1 / \mathrm{PC} 3$. This observation is consistent with the reported inefficient cleavage of a LysLys site in $\beta$-endorphin $(36,37)$ as well as in mutated forms of proneuropeptide $\mathrm{Y}(38)$ and 
prorenin $(39,40)$ in AtT-20 cells. In vitro experiments using small tripeptide substrates also suggest that LysLys sites are inefficiently cleaved by PC1/PC3 (41), although one study reported that $\mathrm{PC} 1 / \mathrm{PC} 3$ cleaves proenkephalin at a LysLys site (42). Coexpression of PC2 in the wild-type gastrin-producing cells resulted in enhanced cleavage of the Lys ${ }^{74} \mathrm{Lys}^{75}$ site with consequent enhanced production of $\mathrm{G} 17$ relative to G34. This result is compatible with our previous studies (21) showing that G17 is the predominant molecular form of gastrin produced in pLJ-gastrin-infected GH3 cells (which express PC2 but not $\mathrm{PC} 1 / \mathrm{PC} 3$ ), as well as the work of others demonstrating that PC2 cleaves a LysLys site in proopiomelanocortin (POMC) $(36,37)$.

Unlike LysLys processing sites, LysArg sites are quite common and are often cleaved by PC1/PC3, PC2, or both enzymes $(36,38,39,41-43)$. Thus, our finding that $\mathrm{Lys}^{74} \mathrm{Arg}^{75}-\mathrm{mu}-$ tated progastrin was cleaved in PC1/PC3-containing AtT-20 cells (G17:G34 $=2: 1$ ) and enhanced with PC2 coexpression (G17:G34 = 4:1) is consistent with the promiscuous nature of LysArg-processing sites for PC1/PC3 and PC2.

Processing of precursors at ArgArg sites is similar to LysArg processing in that it can be performed by $\mathrm{PC} 1 / \mathrm{PC} 3$, $\mathrm{PC} 2$, or both enzymes. Like the wild-type Lys ${ }^{74} \mathrm{Lys}^{75}$ progastrin-producing AtT-20 cells, those cells expressing mutant $\mathrm{Arg}^{74}-\mathrm{Arg}^{75}$ progastrin produced G34 as the predominant molecular form. G17 was the predominant form found in cells coexpressing PC2 and $\mathrm{Arg}^{74} \mathrm{Arg}{ }^{75}$ progastrin. Our findings contrast with a previous report that an ArgArg site in POMC (36) and a mutant $\mathrm{Arg}^{38} \mathrm{Arg}^{39}$ site in proneuropeptide $\mathrm{Y}$ were efficiently cleaved in AtT-20 cells (38). Furthermore, in vitro studies have demonstrated that PC1/PC3 cleaves an ArgArg site in proinsulin (41). Taken together, these observations support the notion that amino acids in the proximity of the dibasic cleavage site are important for enzyme-substrate interactions and that amino acids surrounding $\mathrm{Arg}^{74} \mathrm{Arg}^{75}$ progastrin do not enhance the efficiency of cleavage for PC1/PC3.

Mutant $\mathrm{Arg}^{74} \mathrm{Lys}^{75}$ progastrin was inefficiently processed in AtT-20 cells with or without coexpression of PC2, suggesting that neither PC1/PC3 nor PC2 is capable of ArgLys cleavages in the absence of other substrate site modifications. These data are consistent with reports of others (38) as well as with our previous observations demonstrating inefficient carboxy-terminal processing of mutant $\mathrm{Arg}^{94} \mathrm{Lys}{ }^{95}$ progastrin in $\mathrm{GH} 3$ and MTC 6-23 cells (21). However, the $\mathrm{Arg}^{77} \mathrm{Lys}^{78}$ of prosomatostatin is efficiently processed in AtT-20 cells $(44,45)$, and the $\mathrm{Arg}^{50} \mathrm{Lys}^{51}$ site in POMC can be cleaved in AtT-20 cells transfected with PC2 cDNA (36). These observations illustrate further that the amino acids in the proximity of the dibasic residues are crucial in determining the catalytic activity of PC1/ PC3 and PC2 at ArgLys sites.

Our studies and those of others suggest that PC1/PC 3 and PC2 catalyze the cleavage of LysArg dibasic pairs in a variety of peptide hormone precursors but do not consistently cleave LysLys or ArgArg sites efficiently. Processing at these latter sites by the PCs appears to require a specific secondary structure or sequence of proximate amino acids for full efficacy (46). For PC1/PC3 or PC2 to function as ArgLys cleavage enzymes, there may be a requirement for a well-defined secondary structure similar to that seen in prosomatostatin and POMC. It is also possible that ArgLys sites are the preferred substrates for a distinct prohormone convertase yet to be characterized. Our studies clearly indicate that elucidation of requirements for ef- ficient prohormone cleavage by PCs requires the use of fulllength substrates.

The use of ion-exchange FPLC allowed us to examine the sulfation of gastrin at $\mathrm{Tyr}^{87}$. Although $\mathrm{Tyr}^{87}$ sulfation does not alter the biological activity of amidated gastrin (47), the relative amounts of sulfated and nonsulfated gastrins vary in some disease states (48) and during development (49). Mutation at Lys $^{74}$ Lys $^{75}$ had profound effects on endoproteolysis but did not alter $\mathrm{Tyr}^{87}$ sulfation, suggesting that these two events are independent posttranslational processing reactions. This is consistent with the distinct intracellular sites for $\mathrm{Tyr}^{87}$ sulfation (in the Golgi prior to the trans-Golgi network) and endoproteolysis at dibasic residues (secretory granule) $(10,50)$.

Our data in AtT-20 cells suggest that PC2 but not PC1/ PC3 is responsible for the cleavage of the $\mathrm{Lys}^{74} \mathrm{Lys}^{75}$ site in progastrin and the tissue-specific generation of G17. The physiologic implications of these findings are supported by our observations and those of others (51) that $\mathrm{PC} 2$ is expressed in antral G-cells. Thus, PC2 is a likely candidate to be the progastrin Lys ${ }^{74}$ Lys ${ }^{75}$ cleaving enzyme in vivo.

\section{Acknowledgments}

C. J. Dickinson is the recipient of a Clinical Investigator Award from the National Institutes of Health (NIH) grant K08-DK-01903. This study was supported by NIH grant R01-DK-34306 and by funds from the Michigan Gastrointestinal Peptide Research Center-NIH grant P30DK-34933.

\section{References}

1. Barr, P. J. 1991. Mammalian subtilisins: the long-sought dibasic processing endoproteases. Cell. 66:1-3.

2. Steiner D. F., S. P. Smeekens, S. Ohagi, and S. J. Chan. 1992. The new enzymology of precursor processing endoproteases. J. Biol. Chem. 267:2343523438.

3. Smeekens, S. P., and D. F. Steiner. 1990. Identification of a human insulinoma cDNA encoding a novel mammalian protein structurally related to the yeast dibasic processing protease Kex2. J. Biol. Chem. 265:2997-3000.

4. Seidah, N. G., L. Gaspar, P. Mion, M. Marcinkiewecz, M. Mbikay, and M. Chretien. 1990. cDNA sequence of two distinct pituitary proteins homologous to Kex 2 and furin gene products: tissue-specific mRNAs encoding candidates for pro-hormone processing proteinases. DNA and Cell Biol. 9:415-424.

5. Smeekens, S. P., A. S. Avruch, J. LaMendola, S. J. Chan, and D. F. Steiner. 1991. Identification of a cDNA encoding a second putative prohormone convertase related to PC2 in AtT-20 cells and islets of Langerhans. Proc. Natl. Acad. Sci. USA. 88:340-344.

6. Bailyes, E. M., K. Shennan, A. J. Seal, S. P. Smeekens, D. F. Steiner, J. C. Hutton, and K. Docherty. 1992. A member of the eukaryotic subtilisin family (PC3) has the enzymic properties of the type 1 proinsulin-converting endopeptidase. Biochem. J. 285:391-394.

7. Bennett, D. L., E. M. Bailyes, E. Nielsen, P. C. Guest, N. G. Rutherford, S. D. Arden, and J. C. Hutton. 1992. Identification of the type 2 proinsulin processing endopeptidase as PC2, a member of the eukaryote subtilisin family. J. Biol. Chem. 267:15229-15236.

8. Davidson, H. W., C. J. Rhodes, and J. C. Hutton. 1988. Intraorganellar calcium and $\mathrm{pH}$ control proinsulin cleavage in the pancreatic $\beta$ cell via two distinct site-specific endopeptidases. Nature. (Lond.). 333:93-96.

9. Thomas, L., R. Leduc, B. Thorne, S. P. Smeekens, D. F. Steiner, G. Thomas. 1991. Kex2-like endoproteases PC2 and PC3 accurately cleave a model prohormone in mammalian cells: evidence for a common core of neuroendocrine processing enzymes. Proc. Natl. Acad. Sci. USA. 88:5297-5301.

10. Merchant, J. L., C. J. Dickinson, and T. Yamada. 1994. Molecular biology of the gut: model of gastrointestinal hormones. In Physiology of the Gastrointestinal Tract. 3rd edition. L. R. Johnson, editor. Raven Press, New York. 295-350.

11. Matsumoto, M., J. Park, K. Sugano, and T. Yamada. 1987. Biological activity of progastrin posttranslational processing intermediates. Am. J. Physiol. 87:G315-G319.

12. Hilsted, L., K. Hint, J. Christiansen, and J. F. Rehfeld. 1988. Neither glycine-extended gastrin nor the 1-13 fragment of gastrin 17 influences gastric acid secretion in humans. Gastroenterology. 94:96-110. 
13. Seva, C., C. J. Dickinson, and T. Yamada. 1994. Growth promoting effects of glycine-extended progastrin. Science (Wash. DC). 265:410-412.

14. Calam, J., G. J. Dockray, R. Walker, H. J. Tracy, and D. Owens. 1980. Molecular forms of gastrin in peptic ulcer: comparison of serum and tissue concentrations of G17 and G34 in gastric and duodenal ulcer subjects. Eur. J. Clin Invest. 10:241-247.

15. Rehfeld, J. F., and L.-I. Larsson. 1981. Pituitary gastrins. J. Biol. Chem. 256:10426-10429.

16. Gregory, R. A., and H. J. Tracy. 1964. The constitution and properties of two gastrins extracted from hog antral mucosa. Gut. 5:103-114.

17. Eysselein, V. E., V. Maxwell, T. Reedy, E. Wunsch, and J. H. Walsh. 1984. Similar acid stimulatory potencies of synthetic human big and little gastrins in man. J. Clin. Invest. 73:1284-1290.

18. Walsh, J. H., J. I. Isenberg, J. Ansfield, and V. Maxwell. 1976. Clearance and acid-stimulating action of human big and little gastrins in duodenal ulce subjects. J. Clin. Invest. 57:1125-1131.

19. Shennan, K. I. J., S. P. Smeekens, D. F. Steiner, and K. Docherty. 1991. Characterization of $\mathrm{PC} 2$, a mammalian Kex2 homologue, following expression of the cDNA in microinjected Xenopus oocytes. FEBS (Fed. Eur. Biochem. Soc.) Lett. 284:277-280.

20. Boel, E., J. Vuust, F. Norris, K. Norris, A. Wind, J. F. Rehfeld, and K. A. Marcker. 1983. Molecular cloning of human gastrin cDNA: evidence for evolution of gastrin by gene duplication. Proc. Natl. Acad. Sci. USA. 80:2866-2869.

21. Dickinson, C. J., D. Daugherty, Y. Guo, P. Hughes, and T. Yamada. 1992. Molecular analysis of dibasic endoproteolytic cleavage signals. J. Biol. Chem. 267:21795-21801.

22. Kunkel, T. A. Rapid and efficient site-specific mutagenesis without phenotypic selection. 1985. Proc. Natl. Acad. Sci. USA. 82:488-492.

23. Sanger, F., S. Nicklen, and A. R. Coulson. 1977. DNA sequencing with chain-terminating inhibitors. Proc. Natl. Acad. Sci. USA. 74:5463-5467.

24. Danos, O., and R. C. Mulligan. 1988. Safe and efficient generation of recombinant retroviruses with amphotropic and ecotropic host ranges. Proc. Natl. Acad. Sci. USA. 85:6460-6464.

25. Marino, L. R., T. Takeuchi, C. J. Dickinson, and T. Yamada. 1991. Expression and post-translational processing of progastrin in heterologous endocrine cell lines. J. Biol. Chem. 266:6133-6136.

26. Dickerson, I. M., J. E. Dixon, and R. E. Mains. 1987. Transfected human neuropeptide Y cDNA expression in mouse pituitary cells. J. Biol. Chem. 262:13646-13653.

27. Sevarino, K. A., R. Felix, C. M. Banks, M. J. Low, M. R. Montminy, G Mandel, and R. H. Goodman. 1987. Cell-specific processing of preprosomatostatin in cultured neuroendocrine cells. J. Biol. Chem. 262:4987-4993.

28. Sambrook, J., E. F. Fritsch, and T. Maniatis. 1989. Molecular Cloning: A Laboratory Manual. Cold Spring Harbor Laboratory Press, Cold Spring Harbor NY.

29. Innis, M. A., D. H. Gelfand, J. J. Sninsky, and T. J. White. 1990. PCR Protocols. Academic Press, Orlando, FL.

30. Korman, A. J., J. D. Frantz, J. L. Strominger, and R. C. Mulligan. 1987. Expression of human class II major histocompatibility complex antigens using retrovirus vectors. Proc. Natl. Acad. Sci. USA. 84:2150-2154.

31. Chomczynski, P., and N. Sacchi. 1987. Single-step method of RNA isolation by acid guanidinium thiocyanate-phenol-chloroform extraction. Anal. Biochem. 162:156-159.

32. Sugano, K., J. Park, A. H. Soll, and T. Yamada. 1987. Stimulation of gastrin release by bombesin and canine gastrin-releasing peptides. Studies with isolated canine G cells in primary culture. J. Clin. Invest. 79:935-942.

33. Daugherty, D., C. J. Dickinson, D. Bachwich, T. Takeuchi, and T. Yamada.
1991. Heterologous expression of gastrin in murine thyroid carcinoma cells. Am. J. Physiol. 260:G783-G788.

34. Kemmler, W., J. D. Peterson, and D. F. Steiner. 1971. Studies on the conversion of proinsulin to insulin. J. Biol. Chem. 246:6786-6791.

35. Thorne, B. A., and G. Thomas. 1990. An in vivo characterization of the cleavage site specificity of the insulin cell prohormone processing enzymes. $J$. Biol. Chem. 265:8436-8443.

36. Zhou, A., B. T. Bloomquist, and R. E. Mains. 1993. The prohormone convertases $\mathrm{PC1}$ and $\mathrm{PC} 2$ mediate distinct endoproteolytic cleavages in a strict temporal order during proopiomelanocortin biosynthetic processing. J. Biol. Chem. 268:1763-1769.

37. Day, N. C., H. Lin, J. H. Meador-Woodruff, and H. Akil. 1993. Characterization of proopiomelanocortin processing in heterologous neuronal cells that express PC2 mRNA. Neuropeptides. 24:253-262.

38. Dickerson, I. M., J. E. Dixon, and R. E. Mains. 1990. Biosynthesis and posttranslational processing of site-directed endoproteolytic cleavage mutants of pro-neuropeptide $Y$ in mouse pituitary cells. J. Biol. Chem. 265:2462-2469.

39. Benjannet, S., T. Reudelhuber, C. Mercure, N. Rondeau, M. Chretien, and N. G. Seidah. 1992. Proprotein conversion is determined by a multiplicity of factors including convertase processing, substrate specificity, and intracellular environment. J. Biol. Chem. 267:11417-11423.

40. Landenheim, R. G., N. G. Seidah, G. Lutfalla, and F. Rougeon. 1989. Stable and transient expression of mouse submaxillary gland renin cDNA in AtT-20 cells: proteolytic processing and secretory pathways. FEBS (Fed. Eur. Biochem. Soc.) Lett. 245:70-74.

41. Rufaut, N. W., S. O. Brennan, D. J. Hakes, J. E. Dixon, and N. P. Birch. 1993. Purification and characterization of the candidate prohormone-processing enzyme SPC3 produced in a mouse L cell line. J. Biol. Chem. 268:20291-20298.

42. Breslin, M. B., I. Lindberg, S. Benjannet, J. P. Mathis, C. Lazure, and N. G. Seidah. 1993. Differential processing of proenkephalin by prohormone convertases 1(3) and 2 and furin. J. Biol. Chem. 268:27084-27093.

43. Jean, F. A. Basak, N. Rondeau, S. Benjannet, G. Hendy, N. G. Seidah, M. Chretien, and C. Lazure. 1993. Enzymic characterization of murine and human prohormone convertase-1 ( $\mathrm{mPC1}$ and $\mathrm{hPC1}$ ) expressed in mammalian $\mathrm{GH} 4 \mathrm{Cl}$ cells. Biochem. J. 292:891-900.

44. Korner, J., J. Chun, D. Harter, and R. Axel. 1991. Isolation and functional expression of a mammalian prohormone processing enzyme, murine prohormone convertase 1. Proc. Natl. Acad. Sci. USA. 88:6834-6838.

45. Gomez, S., G. Boileau, L. Zollinger, C. Nault, M. Rholam, and P. Cohen. 1989. Site-specific mutagenesis identifies amino acid residues critical in prohormone processing. EMBO (Eur. Mol. Biol. Organ.) J. 8:2911-2916.

46. Rholam, M., P. Nicolas, and P. Cohen. 1986. Precursors for peptide hormones share common secondary structures forming features at the proteolytic processing sites. FEBS (Fed. Eur. Biochem. Soc.) Lett. 207:1-6.

47. Cantor, P. M. B. Petersen, J. Christiansen, and J. F. Rehfeld 1990. Does sulfation of gastrin influence gastric acid secretion in man? Scand. J. Gastroenterol. 25:739-745.

48. Andersen, B. N., B. Petersen, K. Borch, and J. F. Rehfeld. Variations in the sulfation of circulating gastrins in gastrointestinal diseases. 1983. Scand. J. Gastroenterol. 18:565-569.

49. Brand, S. J., B. N. Andersen, and J. F. Rehfeld. Complete tyrosine- $O$ sulfation of gastrin in neonatal rat pancreas. 1984. Nature (Lond.) 309:456-458.

50. Varro, A. J. Henry, C. Valliant, and G. J. Dockray. 1994. Discrimination between temperature- and brefeldin A-sensitive steps in the sulfation, phosphorylation, and cleavage of progastrin and its derivatives. J. Biol. Chem. 269:2076420770.

51. Scopsi, L., M. Gullo, F. Rilke, S. Martin, and D. F. Steiner. 1995. Proprotein convertases (PC1/PC3 and PC2) in normal and neoplastic tissues: their use as markers of neuroendocrine differentiation. J. Clin. Endocrinol. Metab. 80:294301 